Vol. LXVI 2015

\title{
THE IMPACT OF OCCUPATIONAL HAZARDS IN WORKPLACES - MAINTENANCE, A MAIN TARGET FOR ENSURING THE SAFETY OF WORKING EQUIPMENT
}

\author{
ANTONOV Anca Elena \\ INCDPM "Alexandru Darabont”, Blvd. Ghencea, no. 35 A, Bucharest, 6 county, Romania, email: \\ aantonov@protectiamuncii.ro \\ BUICA Georgeta \\ INCDPM "Alexandru Darabont”, Blvd. Ghencea, no. 35 A, Bucharest, 6 county, Romania, email: \\ georgiana_buica@yahoo.com \\ DARABONT Doru Costin \\ INCDPM "Alexandru Darabont”, Blvd. Ghencea, no. 35 A, Bucharest, 6 county, Romania, email: \\ darabont_d@yahoo.com \\ BEIU Constantin \\ INCDPM "Alexandru Darabont", Blvd. Ghencea, no. 35 A, Bucharest, 6 county, Romania, email: \\ costinbeiu01@gmail.com
}

\begin{abstract}
For use of work equipment having the economic performance and the highest level of safety, it must be ensured that it complies with the conditions set by the manufacturer in terms of putting into service, use and maintenance operations, ensuring appropriate technical and environmental requirements, including appropriate measures and means of protection. The research aimed to identify and analyze the occupational hazards associated to maintenance operations, in terms of the history of the adjustments, maintenance, cleaning and repair, including the case that occur after the incidents, capital repairs and upgrades. The results of the research consisted in the development of recommendations on the effective management of maintenance activities of work equipment and a software model to enable an efficient management of maintenance, as a tool for occupational hazards in companies - premise for increasing the competitiveness of employers in the market economy.
\end{abstract}

Key words: safety, maintenance, work equipment, manufacturer, worker

\section{Introduction}

The modern economy is the result of industrialization and economic and social progress, requiring modern upgraded working facilities and equipment, to ensure high economic efficiency [1]. In order to use work equipment, in terms of economic performance and maximum safety, they must comply with conditions established by the manufacturer, related to commissioning, use and maintenance in order to guarantee technical and environmental requirements including the measures and means of protection [14] [18]. In this regard, in order to guarantee the safe use of working equipment, it is needed to establish the necessary safety conditions for conformity assessment, certification and, if necessary, checking the compliance by technical diagnostics of requirements adopted by the manufacturers in the design and production phase on the risks that may occur during the maintenance activities [4] [5] [14] [15].

2. Maintenance of working equipment $-\mathrm{a}$ tool to guarantee the management and control of occupational hazards in companies

The working equipment must be designed and built so to be able to fulfil their functions and to be used , adjusted and maintained without any risk for the workers when these operations are carried out as required by the manufacturer, and taking into account any foreseeable misuse [14]. The aim of taken measures must be to eliminate any risk throughout the foreseeable lifetime of the machinery, including in the phases of transport, assembly, disassembly, dismantling and disposal. The working equipment must be supplied with all the essential special equipment and accessories so it can be adjusted, maintained and 
used safely. As activity at work, maintenance can affect the safety and health of workers, both those who use working equipment, as well as those directly involved in it [5] [16] [17].

An important objective of management efficiency in maintenance activities of working equipment in use is to ensuring a maximum level of safety by using safe working equipment and adequate methods and procedures taking into account the regulations in force.

\subsection{Accidents at work due to maintenance operations}

At EU level, according to EUROSTAT, the most working accidents were recorded in maintenance activities, which along with repairs and adjustments, are on the fourth rank on the list of top ten working processes for the highest number of fatalities in the 2003-2005 period (EUROSTAT-SEAM). Accidents have a tendency to increase more likely not due to normal operation, but during repair, maintenance, cleaning, adjusting, etc.

Nationally, according to the NIS, there is an increase in the rate of accidents at work in maintenance activities - activity category registered to the repair, maintenance and installation of facilities and working equipment - in 2011 are recorded the most working accidents [18]. In Figure 1 is drawn the allocation of working accidents in the EU, according to existing data on EUROSTAT, and processed by the authors.

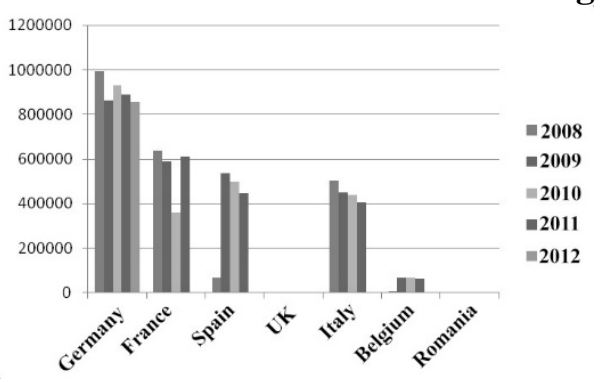

a) Total number of accidents

Figure 1: Accidents at work in the period 2008-2012

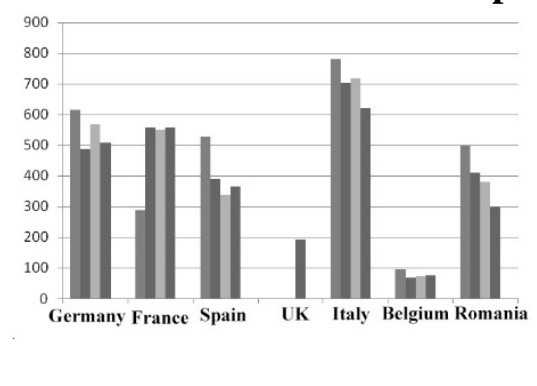

b) Number of fatalities

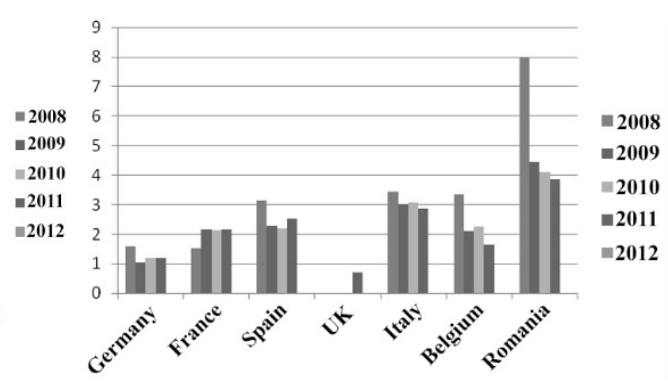

c) The rate

The statistics on accidents at work produced at national level, processed in the study, revealed that there is an increase of the number of working accidents at macro regions level and regional, the maintenance activity is registered to the Repair, maintenance and installation of facilities and working equipment, are shown in Figure 2 [18].

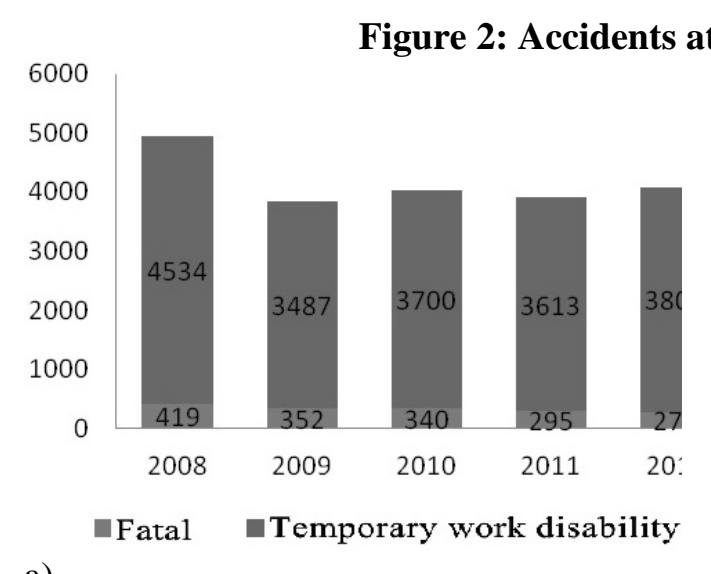

a)

Total number of accidents

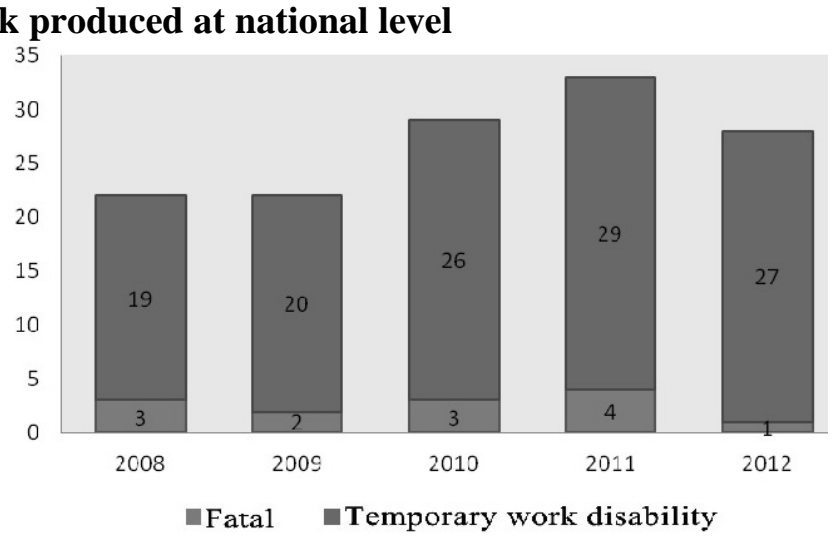

b)

In accordance with European standard EN 13306: 2010, maintenance refers to the „Combination of all technical, administrative and managerial actions during the life cycle of an item intended to retain it in, or restore it to a state in which it can perform the required function" [10].

Maintenance is a generic term for a variety of operations from very different sectors and in all kinds of environments, which include activities of: inspection, testing, measurement, replacement, adjustment, repair, fault detection, replacement of parts of an item, service, lubricating, cleaning [2] [6] [12] [16] [17] [18]. 
Maintenance is essential to ensure to ensure continuity of productivity, to manufacture top quality products and to maintain the company's competitiveness. This has also an impact on safety and health at work. First, a good maintenance is essential to maintain the safety and reliability of working equipment and work environment. Secondly, maintenance itself is a high risk activity and should be performed safely, with adequate protection for maintenance workers and other persons present in the workplace.

The maintenance activity carried out correctly and on time, improves the availability of machinery and working equipment from a company and maintains the reliability level at a quota that allows a good continuity of the production process and increases total length of life.

\subsection{Risks due to maintenance operations}

From studies on the evaluation of risk levels and working conditions while performing maintenance operations on the four categories of working equipment, it were found that the highest weight are mechanical and electrical risks [4] [6] [7] [8] [13].

From statistical analysis of working accidents recorded, it can be appreciated that a high percentage of incidents are due to: not planning preventive maintenance operations; outdated maintenance failure to comply, by the workers, with safety instructions laid down by the manufacturer through specifications and with the management techniques and procedures specific to maintenance activity established by the company.

Figure 3 shown the weight of occupational risks identified in maintenance activities [5] [6] [11] [12].

\section{Figure 3: The weight of risk factors identified in the maintenance activity}

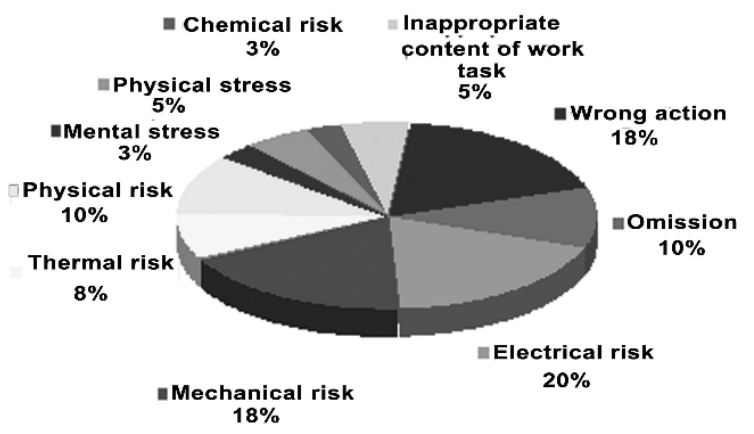

During performing maintenance operations, workers must consider compliance with relevant health and safety requirements for the safe use of work equipment. Figure 4 summarizing the health and safety requirements applicable to specific working equipment maintenance operations [7]:

Figure 4: Identifying the health and safety requirements applicable for working equipment for specific maintenance operations

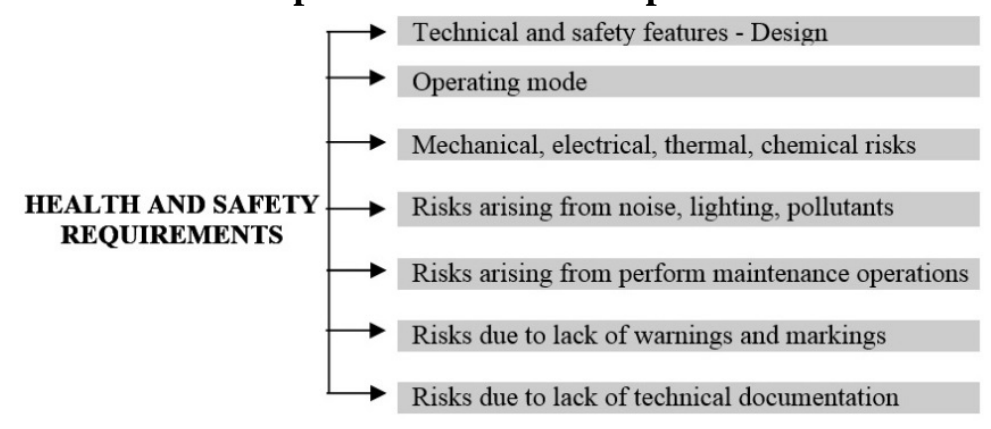

Risk management activities relating to maintenance of working equipment is based on their technical documentation, regarding the conditions of use set by the instructions in the technical manual / User manual/ Technical instruction [18].

The technical instructions must specify, in particular, the adjustment and maintenance operations to be performed and to indicate their frequency. The technical instructions must contain a list of parts or machinery parts to be examined regularly to be able to identify the excessive use, indicating the periodicity of these examinations (in terms of time or number of cycles) and must specify the type of the checks or necessary tests and equipment to be used. Also, the criteria should be indicated to determine if 
the used part must be repaired or replaced and specified methods and procedures to be followed to ensure that adjustment and maintenance operations can be carried out safely.

Safety and health measures to be taken during maintenance operations must be indicated. Technical instructions should include, where appropriate [14] [16] [18]:

- Information about separation of energy sources, lockout/tag out, dissipation of residual energy, and checking the safety status of machinery

- Measures to guarantee the safety of maintenance operations to be carried out while the machine is running;

- Methods to be used to remove or replace parts safely;

- Precautions to be taken to clean internal parts which have contained dangerous substances.

Manufacturer's instructions must indicate the type of checks to be carried out on such parts (e.g. visual inspections, functional checks or tests), the frequency of such inspections (e.g. the number of duty cycles or duration of use) and criteria to repair or replace those parts [18].

These criteria are elements to guarantee occupational risk management in maintenance operations performed by workers.

\subsection{Technical instruments for management of maintenance activities}

Technical tools for the management of maintenance activities of working equipment in use have been developed in order to prevent working accidents and occupational diseases - a prerequisite for increasing the competitiveness of employers in the market economy [16] [17] [18].

It was considered in the study research, identification and analysis of occupational hazard and risk of injury and occupational disease related to maintenance activities for four categories of working equipment that perform cutting processing (milling) and cold plastic deformation (mechanical, hydraulic, pneumatic presses, and electrical equipment of machinery) [18]. In this regard, it has been developed a user guide for working equipment maintenance activities through a set of recommendations on the effective management of maintenance activities for working equipment and a software model to enable efficient management of maintenance activities for working equipment as a tool to control occupational hazards in companies and employers, prerequisite for increasing competitiveness in the market economy [5] [6] [18]. The user guide is a useful tool for employers operating in the national economy in order to ensure the necessary support compliance with safety and health rules in all stages of the maintenance activities in order to implement minimum health and safety requirements and the requirements set by the company to manage in the most efficient way the risk management [18]. It is a necessary tool for improvement, especially in the working environment, to guarantee a better level of health and safety of workers, being developed as a reference document, with voluntary application in order to inform about the risks and providing practical tips for risk prevention of working accidents and professional diseases of workers exposed in use of such working equipment in the workplaces [18]. The second technical tool for the management of maintenance activities developed in the study is a model of software, which aims to ensure tracking real-time control of working equipment in use, through a risk analysis in terms of the history of the adjustment, maintenance, repair and cleaning, including situations that occur after some events, capital repairs and upgrades [5] [6] [18]. The software on the management of maintenance activities of working equipment - MENTSOFTCST - allows efficient management of maintenance activity of working equipment, providing tracking of scheduled maintenance activities, the recording of performed operations on each part of working equipment, proper and safe monitoring of working equipment in use. The maintenance software MENTSOFTCST records data resulting from maintenance operations carried out as well as identifying the nonconformities, allowing the maintenance operators and technical departments within the companies to adopt technical and organizational necessary measures to ensure applicable essential health and safety requirements, in order to operate the working equipment properly and safely [5] [18].

In figure No. 5 is shown a program window with the component and technical characteristics of working equipment subject to maintenance operations [18]. 


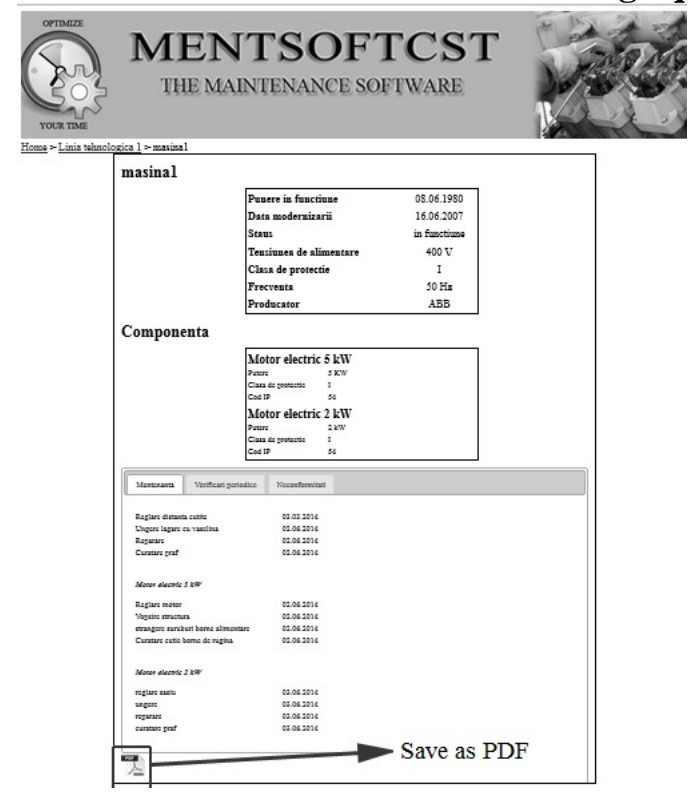

\section{Conclusion}

The research study aimed to develop tools needed to ensure compliance of working equipment in use in accordance with the provisions of Directives 2009/104 / EC, 2009/127 / EC, 2006/42 / EC, Law no. 319 / 1996 on safety and health at work and the GD no.1146 / 2006. The research started from the need to ensure compliance with essential health and safety requirements set out in Annex 1 of Directive 2006/42 / EC, in conjunction with the requirements of Directive 2009/127 / EC and the minimum safety and health requirements from Directive 89/655 / EEC and Directive 2009/104 / EC.

The research study aimed to identify and analyse occupational hazards and risks associated with maintenance activities, in terms of the history of the adjustment, maintenance, repair and cleaning, including situations that occur after some events, capital repairs and upgrades.

Research conducted aimed to support the Romanian employers to ensure the necessary conditions for use in complete safety of working equipment and to manage the occupational hazards for workers, in order to improve safety and health in workplaces, respectively OSH management activities.

Occupational hazards and risks related to injury and occupational disease identified in maintenance activities require to set and to include some of measures into the integrated management system for companies by managing the maintenance activities of working equipment in use, in accordance with European Directives.

\section{References}

- Alsyouf, I., (2007) - The role of maintenance in improving companies'productivity and profitability, International Journal of Production Economics, vol. 105, Issue 1, pg 70-78.

- Antonov A., (2011a), Machine maintenance - requirement for safety and health of workers, OSHA campaign: Together for safe and healthy workplaces, 30 of September, 2010 Constanta, Romania; 25 of November, 2010 Bucharest, Romania

- Antonov A., Dobre A, Buica G., (2011b), The real costs of road accident vs. cutting the costs of machinery maintenance, OSHA campaign Road safety and maintenance of motor vehicles in Romania, 9 of June, 2011 Bucharest, Romania; OSHA EUROmainntenance campaign Together for safe and healthy workplaces, 23-24 of September, 2010 Bucharest, Romania

- Antonov A., Buica G., (2013), Management of risk factors - a tool for ensuring the competitiveness requirements of companies in the energy sector, OSHA seminar Together for risk prevention, OSHA campaign Healthy workplaces, 25 of July, 2013 Bucharest, Romania

- Antonov A., Buica G., Beiu C. (2013), Management and control of occupational risk in the maintenance activities of work equipment in companies using software tools, Environmental Engineering and Management Journal, Volume 13, No. 6/2014, 1361-1354, Symposium on Occupational Health and Safety - SESAM 2013,

- Antonov A., Buica G., Beiu C. (2013), Software de mentenanță a echipamentelor de muncă, Revista OBIECTIV nr.2 /2014, pag 26-29 
- Buica G., (2011), Beiu C, Antonov A, Oltean M, Cotrigăşeanu G (2014), Management of risks regarding the means and equipment of protection used in electrical installations, CIGRÉ Regional South-East European Conference - RSEEC 2014

- Buica G., (2011), Prevention of electrical risc and maintenance, OSHA campaign Together for safe and healthy workplaces, 23-24 of September, 2010 Bucharest, Romania

- Buica G., (2012), Safety measures - tools for reducing the cost of working accidents in electrical installations, Environmental Engineering and Management Journal, 11, 1247-1255.

- CEN- EN 13306:2010- Maintenance - Maintenance terminology

- 11. Darabont A., Pece S., Dascalescu A., (2001a), Safety and Health Management, vol. 1, Agir Press, Bucharest, Romania, 140-143

- Darabont A., Pece S., Dascalescu A., (2001b), Safety and Health Management, vol. 2, Agir Press, Bucharest, Romania, 81-113

- Dobra R., Buica G, Pasculescu D, Leba M (2013), Safety Management Diagnostic Method Regarding Work Cost Accidents from Electrical Power Installations, In: Recent Advances in Industrial and Manufacturing Technologies, WSEAS International Conference, Athena, Greece, vol. 1 , 58-63, On line at: http://www.wseas.us/elibrary/conferences/2013/Vouliagmeni/INMAT/INMAT-08.pdf

- European Commission, (2010), Guide to application of the Machinery Directive 2006/42/EC, 2nd Edition, June 2010, European Commission Enterprise and Industry, On line at: http://ec.europa.eu/enterprise/sectors/mechanical/files/machinery/guide_application_directive_20 06-42-ec-2nd_edit_6-2010_en.pdf.

- https://osha.europa.eu/fop/romania/ro/legislation/hotarare_1146_30_august_2006.shtml

- INCDPM, (2013a), Guide for the application of GD No.1146/2006 regarding the minimum safety and health requirements for the use of work equipment by workers (in Romanian), National Institute of Research and Development for Occupational Safety Alexandru Darabont, Bucharest, Romania, Online at: http://www.inpm.ro/files/publicatii/2013-05.01-ghid-t.pdf

- INCDPM, (2013b), Guide for implementation of Romanian legislation regarding the conditions for placing on the market of machine, GD no.1029/2008 (in Romanian), National Institute of Research and Development for Occupational Safety Alexandru Darabont, Bucharest, Romania, Online at: http://www.inpm.ro/files/publicatii/2013-03.4-ghid.pdf.

- INCDPM, (2014), Occupational Risk management in maintenance activities of working equipment in order to prevent working accidents and occupational diseases - a prerequisite for a more competitive employers in market economy (in Romanian), National Institute of Research and Development for Occupational Safety Alexandru Darabont, Bucharest, Romania 